\title{
Euphorbia talassica (E. sect. Esula, Euphorbiaceae), a new species of leafy spurges from the Western Tian-Shan
}

\section{Lazkov, Georgy A.}

2019-02

Lazkov , G A \& Sennikov , A N 2019 , ' Euphorbia talassica (E. sect. Esula, Euphorbiaceae), a new species of leafy spurges from the Western Tian-Shan ' , Annales Botanici Fennici , vol. 56 , no. $1-3$, pp. 135-143 . https://doi.org/10.5735/085.056.0119

http://hdl.handle.net/10138/303894

https://doi.org/10.5735/085.056.0119

cc_by_nc_sa

publishedVersion

Downloaded from Helda, University of Helsinki institutional repository.

This is an electronic reprint of the original article.

This reprint may differ from the original in pagination and typographic detail.

Please cite the original version. 


\title{
BioOne COMPLETE
}

\section{Euphorbia talassica (E. sect. Esula, Euphorbiaceae), a New Species of Leafy Spurges from the Western Tian-Shan}

\author{
Authors: Georgy A. Lazkov, and Alexander N. Sennikov \\ Source: Annales Botanici Fennici, 56(1-3) : 135-143 \\ Published By: Finnish Zoological and Botanical Publishing Board \\ URL: https://doi.org/10.5735/085.056.0119
}

BioOne Complete (complete.BioOne.org) is a full-text database of 200 subscribed and open-access titles in the biological, ecological, and environmental sciences published by nonprofit societies, associations, museums, institutions, and presses.

Your use of this PDF, the BioOne Complete website, and all posted and associated content indicates your acceptance of BioOne's Terms of Use, available at www.bioone.org/terms-of-use.

Usage of BioOne Complete content is strictly limited to personal, educational, and non-commercial use. Commercial inquiries or rights and permissions requests should be directed to the individual publisher as copyright holder.

BioOne sees sustainable scholarly publishing as an inherently collaborative enterprise connecting authors, nonprofit publishers, academic institutions, research libraries, and research funders in the common goal of maximizing access to critical research. 


\title{
Euphorbia talassica (E. sect. Esula, Euphorbiaceae), a new species of leafy spurges from the Western Tian-Shan
}

\author{
Georgy A. Lazkov ${ }^{1}$ \& Alexander N. Sennikov²,3
}

1) Laboratory of Flora, Institute of Biology, Kyrgyz Academy of Sciences, 720071 Bishkek, Kyrgyz Republic

2) Botanical Museum, Finnish Museum of Natural History, P.O. Box 7, Fl-00014 Helsinki, Finland ("corresponding author's e-mail: alexander.sennikov@helsinki.fi)

3) Herbarium, Komarov Botanical Institute of Russian Academy of Sciences, Prof. Popov Str. 2, RU-197376 St. Petersburg, Russia

Received 20 Aug. 2018, final version received 15 Oct. 2018, accepted 15 Oct. 2018

Lazkov G.A. \& Sennikov A.N. 2019: Euphorbia talassica (E. sect. Esula, Euphorbiaceae), a new species of leafy spurges from the Western Tian-Shan. - Ann. Bot. Fennici 56: 135-143.

A species of Euphorbia sect. Esula (Euphorbiaceae) from the Western Tian-Shan, Central Asia, is described as new to science. Euphorbia talassica sp. nova occurs in the Talas Mountain Range in Kazakhstan and Kyrgyzstan, and falls into E. ser. Andrachnoides because of its relatively short and broad leaves. Euphorbia talassica is most similar to E. irgisensis, from which it differs by having a slender and spreading rootstock ( $v s$. a vertical taproot), and incrassate ( $v s$. thin) leaves. The new species also grows at much higher elevations. Euphorbia ser. Andrachnoides is overviewed for Central Asia and adjacent areas, with seven species discussed and mapped.

\section{Introduction}

Euphorbia subgen. Esula sect. Esula (Euphorbiaceae) is one of the most species-rich group of spurges. It includes at least 96 species of perennial herbs or subshrubs with alternate, linear to elliptic (or ovate) leaves and four cyathial glands that are semilunate or trapezoidal, and with two horn-like appendages (Riina et al. 2013).

Sixteen species of E. sect. Esula are placed in the Irano-Turanian floristic element (Geltman 2015), which is characteristic of arid lowlands and mountains of Turkey, Iran, Afghanistan, Central Asia, northwestern China and Mongolia (Takhtajan 1986). Of those, ten species are present in Central Asia (Nasimova 1983).
The taxonomy of E. sect. Esula in Central Asia was developed by Prokhanov (1949, 1964). Earlier Prokhanov (1933) had described the majority of species in this group. His works (Prokhanov 1933, 1949, 1964) laid a firm basis for further taxonomic studies on Euphorbia in Central Asia and the former USSR as a whole.

Prokhanov (1933) examined a specimen (Kultiasov 18a) of E. sect. Esula ser. Andrachnoides from the Talas Alatau Mts., which he tentatively included in E. irgisensis (as Tithymalus irgisensis) but noted the differences in the plant habit and pubescence, as well as in the distribution area. These differences, he assumed, may indicate a species-level distinction which he was not able to confirm due to the paucity of material. 
However, in further works Prokhanov (1949) did not mention the presence of any species of $E$. ser. Andrachnoides in the Western Tian-Shan.

Later (Gamajunova 1963) such plants were erroneously referred to as E. tianshanica, a species of E. sect. Holophyllum. This section is characterized by typically very broad leaves, and four or five cyathial glands that are elliptic or reniform and lack appendages (Prokhanov 1949, Riina et al. 2013). These characters are quite different from those of the plants from the Western Tian-Shan. Besides, E. tianshanica is endemic to the area surrounding the western part of lake Ysyk-Köl (Prokhanov 1949), and its occurrence in the Western Tian-Shan is highly unlikely. In spite of this apparent mismatch, E. tianshanica (syn. E. prokhanovii) was mentioned as being present in the Talas Alatau by Karmyscheva (1973, 1982) and Nasimova (1983).

After discovering a population of this taxon in the Kyrgyz part of the Talas Alatau, and seeing good photographs of the taxon from Kazakhstan, we became convinced that the differences between these plants and E. irgisensis are stable and the plants belong to an undescribed species of $E$. ser. Andrachnoides.

\section{Material and methods}

Field work was conducted in the Western TianShan to complete the information published in the latest checklist of vascular plants of Kyrgyzstan (Lazkov \& Sultanova 2014). Taxonomic literature (Prokhanov 1933, 1949, 1964, Baikov 2007, 2009) was examined to determine the relationships of the new species.

The species description follows the standards of Prokhanov (1933, 1949); terminology follows Berry et al. (2016). The species distribution was traced from literature (Prokhanov 1933, Karmyscheva 1973) and online resources (www. plantarium.ru). Distribution data on the related species in Central Asia were obtained from floristic and taxonomic literature (e.g. Nasimova 1983, Baikov 2009). Distribution maps were made using the same procedure as in Lazkov and Sennikov (2017).

Toponyms and personal names in the Karakalpak, Kazakh, Kyrgyz and Turkmen lan- guages were transliterated according to the current national Latin scripts. The romanization of the taxonomic authors' names follows the original publications, as advised in Rec. 46B.1 in Turland et al. (2018).

\section{Taxonomy}

Euphorbia talassica Lazkov \& Sennikov, sp. nova (E. sect. Esula ser. Andrachnoides; Figs. 1 and 2)

TyPE: Kyrgyzstan. Talas Range (southern side): near the confluence of Jamgyr and Myrzash Rivers (right tributary of Kara-Kysmak river), on screes among dwarf juniper thickets, $2720 \mathrm{~m}$ a.s.1., $42.170603^{\circ} \mathrm{N}, 71.537167^{\circ} \mathrm{E}, 13$ June 2018 G.A. Lazkov (holotype LE; isotypes FRU, MW). — OTHER SPECIMENS (PARATYPES), OBSERVATIONS AND RECORDS: Kazakhstan. Aqsý-Jabaǵyly Nature Reserve: Kishi-Qaiyńdy, 18 August 1922 M.V. Kultiasov 18 a (TASH); Kóksa1 (Karmyscheva 1973); Qasqabulaq, 16 July 2017 V. Kolbintsev (www. plantarium.ru); Úlken-Qa1yńdy, 18 June 2018 V. Kolbintsev (www.plantarium.ru).

Eтymology: The species name is derived from the Talas Mountain Range.

Species nova a Euphorbia irgisensi rhizomatibus tenuibus (nec radice verticali), foliis crassioribus, nec non glabritie bene differt. A Euphorbia saurica ovario glabro, cyathii foliis viridibus margine rubescentibus (nec flavescentibus), nec non umbellae terminalis radiis paucioribus (4-6, nec 8-10) dignoscitur.

Perennial herbs $10-25 \mathrm{~cm}$ tall, slightly glaucous, nearly glabrous. Rootstock slender, spreading, branched. Caudex slightly branched, with remnants of old stems. Stems erect, a few, slender, not overwintering, glabrous; sterile stems present, not overtopping inflorescence, unbranched; fertile stems with flowering branches in upper third or half, with or without short sterile branches in lower half. Leaves alternate, incrassate, stipules absent; leaves on sterile stems narrowly oblong or oblong-obovate, $1.5-2 \times 0.4-0.6 \mathrm{~cm}$, petioles $1-1.2 \mathrm{~mm}$ long; leaves on fertile stems elliptical, slightly ovate or obovate, or oblong-obovate, broadest at middle part, $0.8-2 \times 0.4-0.9 \mathrm{~cm}$, glabrous or with a few hairs at base, uninervous below, petioles less than $1 \mathrm{~mm}$ long. Inflorescence a terminal pseu- 
Fig. 1. Euphorbia talassica in Kyrgyzstan.

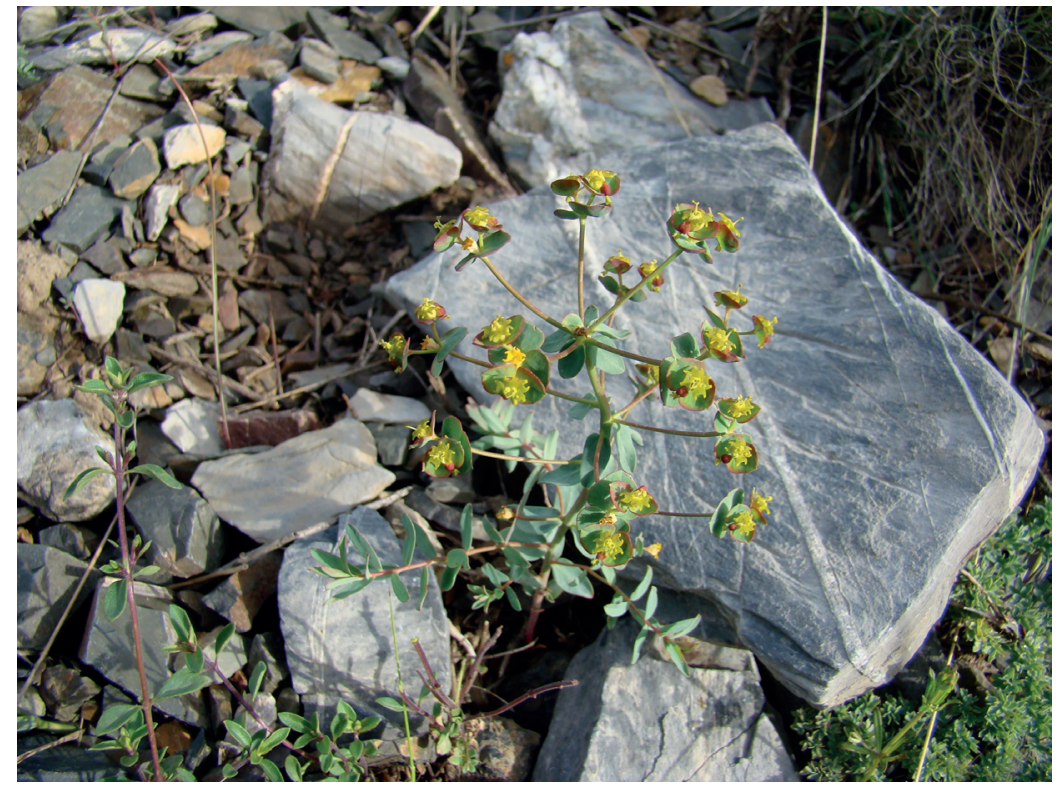

dumbel, with a few to several lateral branches below; terminal pleiochasial branches dichotomous, usually 4-6; pleiochasial bracts 5 , ovate or subrotund to oblong-ovate, $0.8-1.5 \times 0.5-$ $0.8 \mathrm{~cm}$; dichasial bracts 2 , broadly triangularovate, green with reddish margins. Cyathium ca. $2 \mathrm{~mm}$ long; involucre lobes rounded, ciliate on margins; cyathial glands 4, yellowish, appendages crescent-shaped, 2-horned, horns long and thin. Styles 2-3 mm long, half-fused, slightly bifid. Ovary 2-3 mm long, with 3 vertical furrows, tuberculate, glabrous. Mature fruits not seen. Flowering in June-July.

DisTRIBUTION AND HABITAT. Western TianShan: Talas Range in Kazakhstan and Kyrgyzstan (Figs. 3 and 4). On screes in the middle mountain belt, at elevations of 2150-3200 m a.s.1., often among dwarf juniper thickets. We do not evaluate the protection status because of absence of population data. All known localities of E. talassica in Kazakhstan are within the Aqsý-Jabaǵyly Nature Reserve. The locality in Kyrgyzstan is not protected.

\section{Discussion}

Euphorbia talassica is classified in E. ser. Andrachnoides because of its relatively short and broad leaves, in agreement with the provisional identification by Prokhanov (1933). The leaf characters strikingly distinguish this species from $E$. jaxartica, the only sympatric species of the same section which was treated as belonging to $E$. ser. Virgatae (Prokhanov 1964). Phylogenetic analyses (Riina et al. 2013, Pahlevani et al. 2017) do not support separation of $E$. ser. Virgatae (leaves long and very narrow) from $E$. ser. Esulae (leaves long but broader), into which the former series should be included. On the other hand, the only species sampled from E. ser. Andrachnoides, E. buhsei, seems to be significantly different from the core of the section in both analyses.

Baikov (2007) suggested that E. ser. Andrachnoides, as circumscribed by Prokhanov (1964), may be polyphyletic and its xerophytic, broad-leaved species may have resulted from parallel adaptations of different mesophytic, narrow-leaved species to arid conditions. That hypothesis cannot be confirmed or rejected because the monophyly of E. ser. Andrachnoides has not been tested; nevertheless, we consider it unlikely that E. talassica is derived directly from E. jaxartica. Euphorbia jaxartica has a strong vertical taproot with an abundantly branched caudex, typical of E. virgata s. lato (Prokhanov 1933), whereas E. talassica develops a very slender, spreading rootstock. 


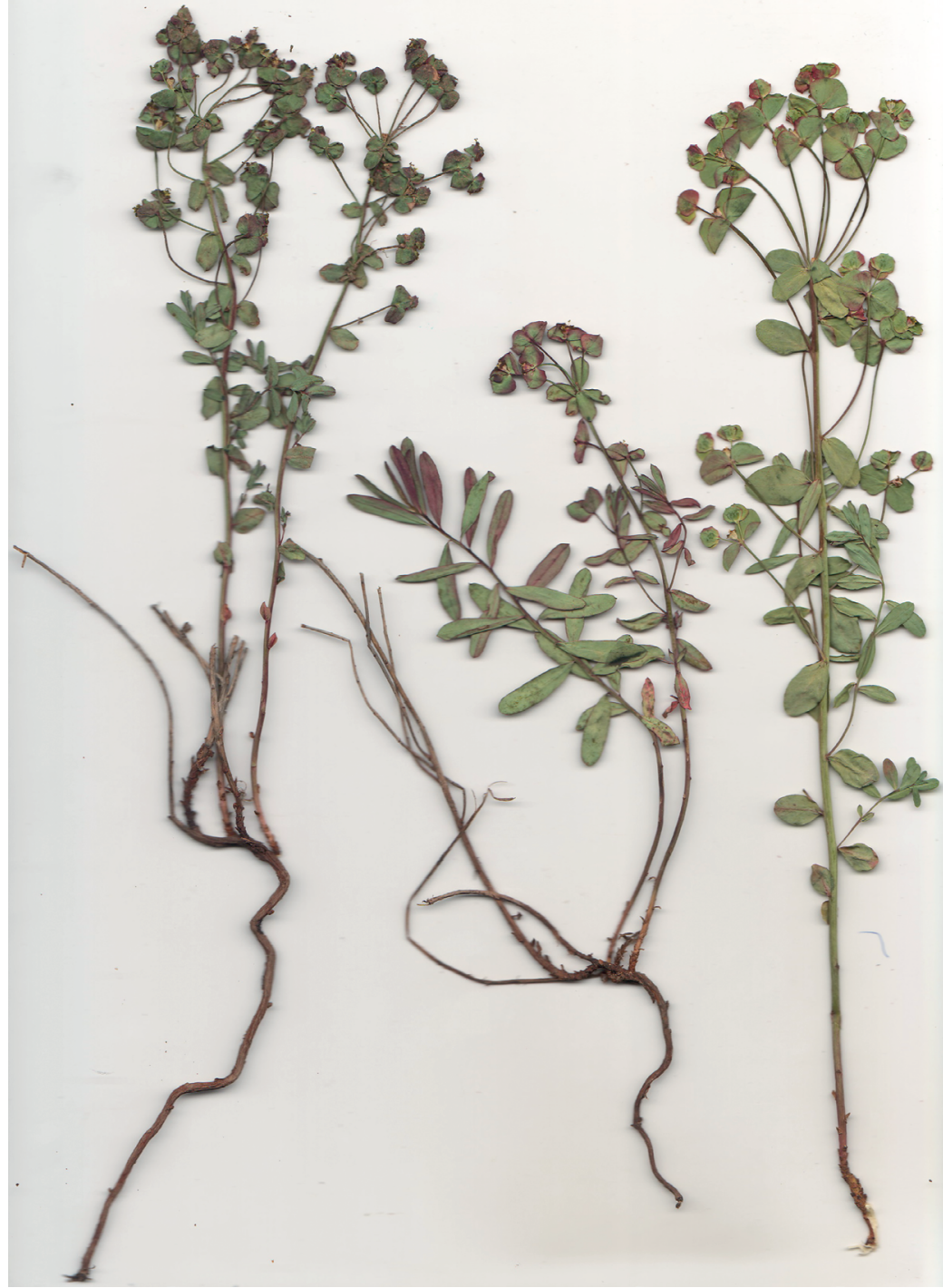

Fig. 2. Holotype of Euphorbia talassica.
As a rule, the species of E. ser. Andrachnoides in Central Asia and adjacent areas have relatively narrow distributions and a high level of geographical separation (Prokhanov 1949, Nasimova 1983, Baikov 2007, 2009). They are largely confined to arid areas. With the new species described here, seven species of the group are known from this territory (Fig. 4). Their diagnostic characters are listed in Table 1 and briefly discussed below.

Euphorbia buhsei stands apart from the other species because of its subshrubby habit with highly lignified stems. It is distributed in extensive areas in Iran and adjacent Turkmenistan
(Rechinger \& Schiman-Czeika 1964, Nasimova 1983, Nikitin \& Geldykhanov 1988, Pahlevani et al. 2017), with isolated localities in eastern Turkmenistan (Pojarkova 1950) and adjacent Uzbekistan (Pazij 1959). Its only record from Afghanistan (Rechinger \& Schiman-Czeika 1964) was based on misidentification (Pahlevani et al. 2017), and its occurrence in Uzbekistan and adjacent parts of Turkmenistan was considered doubtful (Pahlevani et al. 2017) but without evidence. There are data on this species from China (Xinjiang) and Mongolia (Govaerts et al. 2000, and http://wcsp.science.kew.org/namedetail.do?name_id=78745), which disagree with 
Fig. 3. Distribution of Euphorbia talassica. Localities in Kazakhstan are based on Prokhanov (1933), Karmyscheva (1973), and www.plantarium.ru.

Fig. 4. Distribution areas of central Asian species of Euphorbia ser. Andrachnoides. Sources: Kryshtofovich (1931), Prokhanov (1933, 1949), Gamajunova (1963), Rechinger \& Schiman-Czeika (1964), Nasimova (1983), Nikitin \& Geldykhanov (1988), Baikov (1999, 2007), Pahlevani et al. (2017), Nasseh et al. (2018), www.plantarium.ru, own data. Doubtful records not shown.
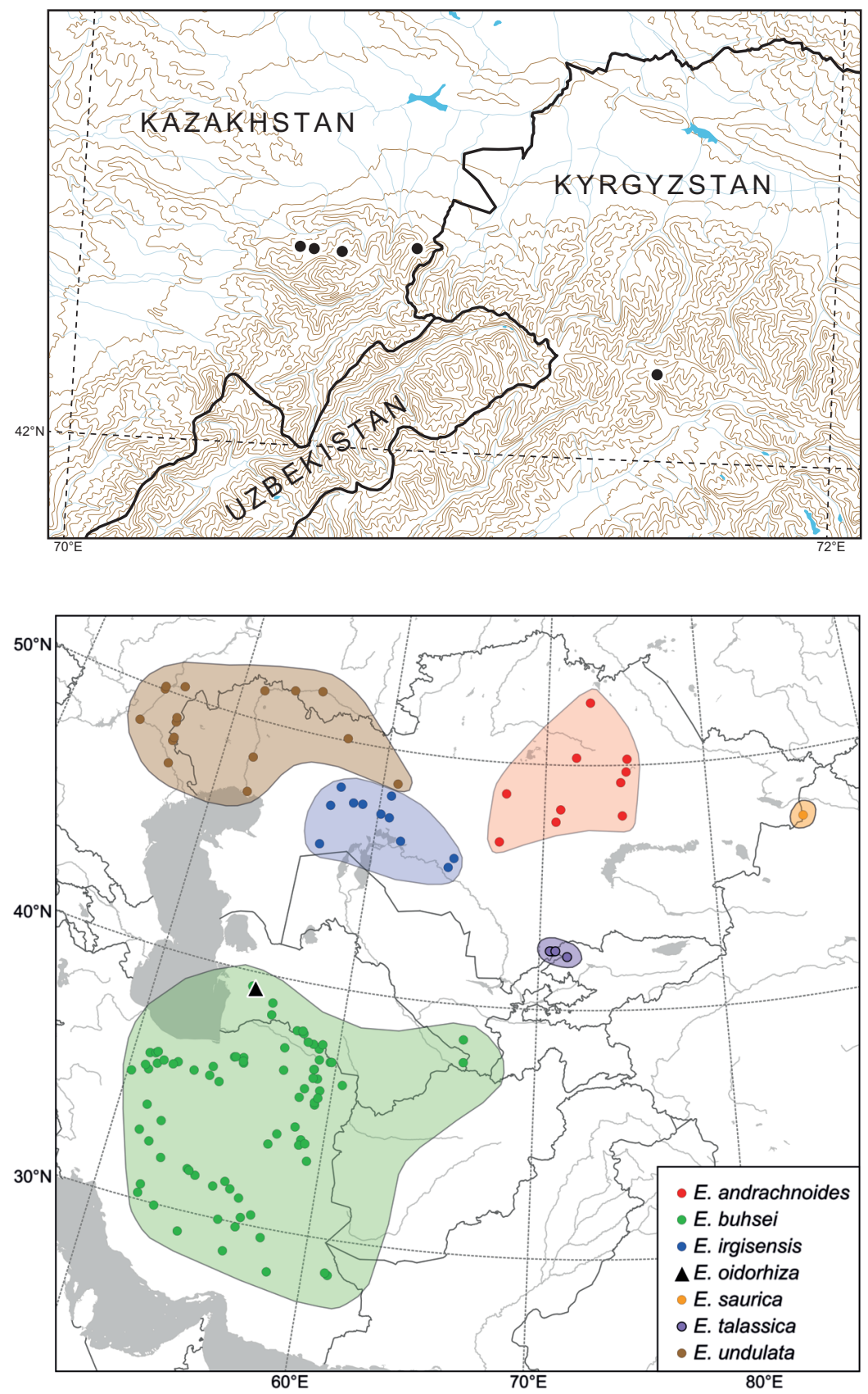

the national checklists (Gubanov 1996, Ma \& Gilbert 2008). Given the limited presence of the species in southwestern Uzbekistan and its complete absence from Tajikistan and Kyrgyzstan (Shibkova \& Kinzikaeva 1981, Lazkov \& Sultanova 2014), its presence in China and Mongolia is highly unlikely. This species grows in the mountains on rocky and gravelly slopes from foothills to the upper mountain belt (Nikitin \& Geldykhanov 1988).

Euphorbia oidorhiza (syn. E. balkhanica) is confined to the Kiçi Balkan (Malyi Balkhan) Mts. in Turkmenistan (Nasimova 1983, Nikitin \& Geldykhanov 1988), where it was found on pebble conglomerates (Tarassov 1952b). This species seems to be unique in the group because 


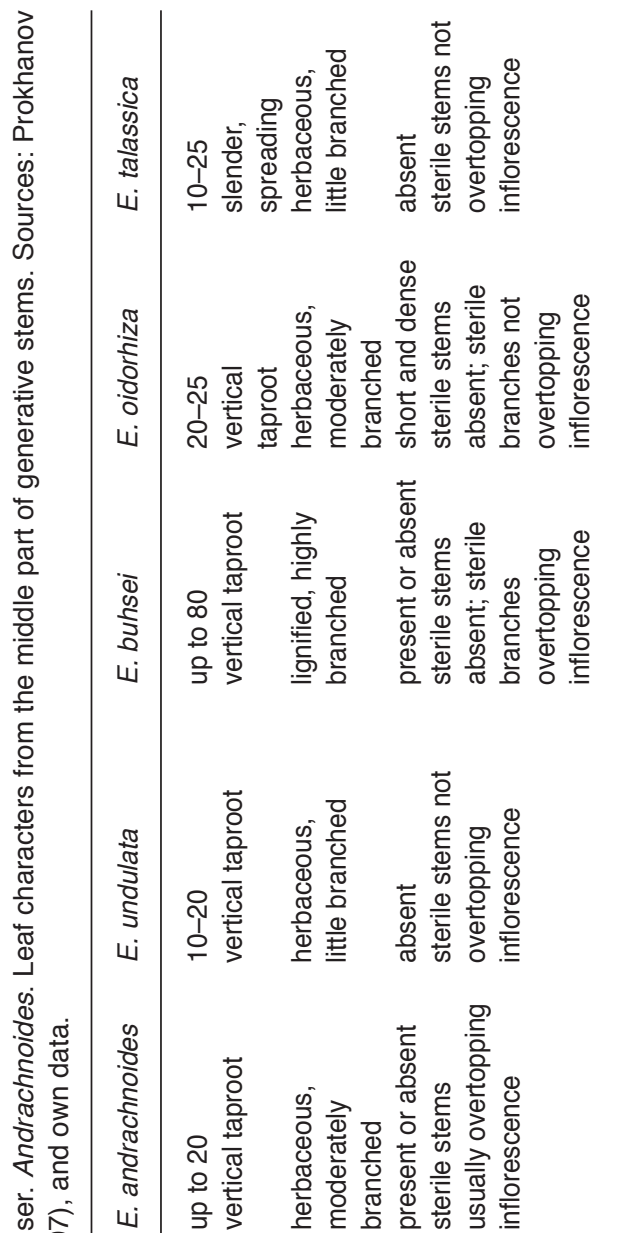

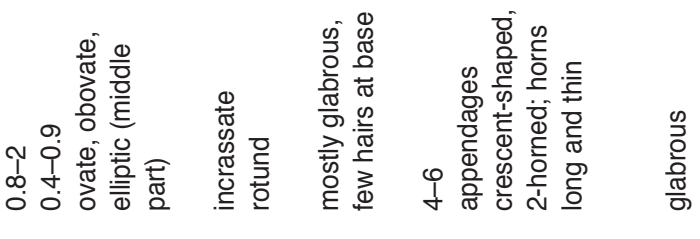

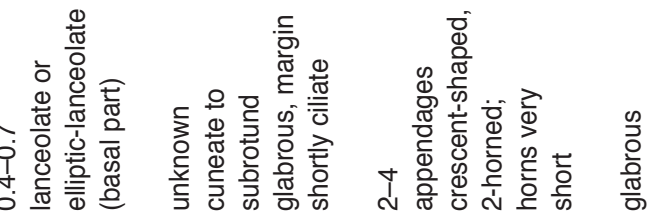

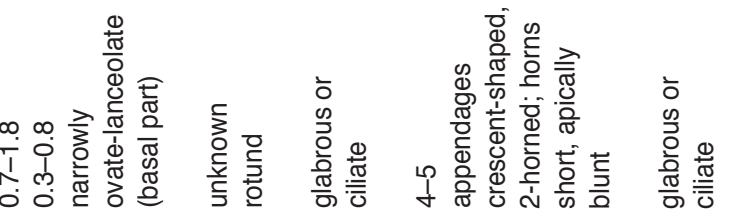

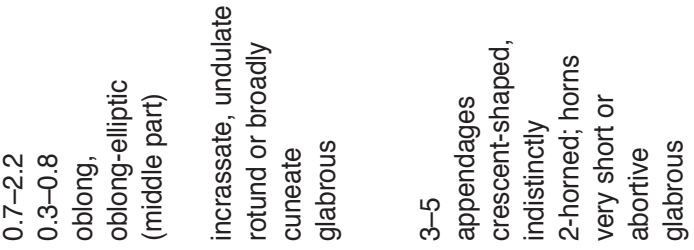

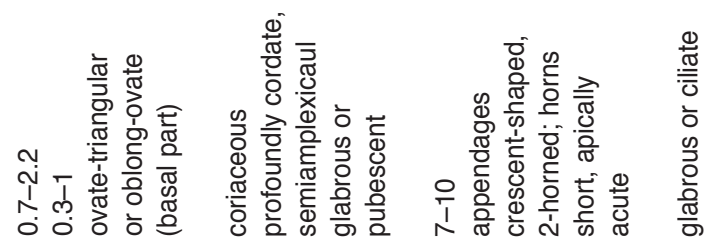
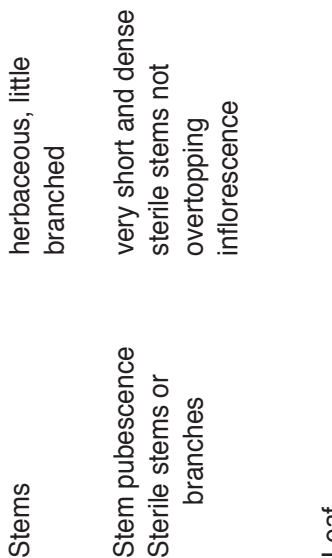

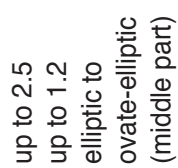

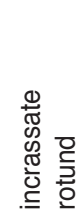

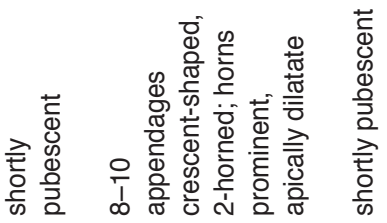

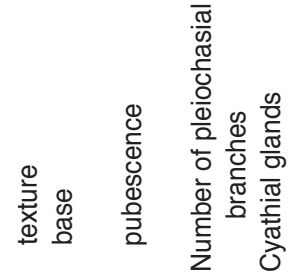


of its tuber-like roots; it occurs within the distribution area of $E$. buhsei but readily differs from the latter in its low stature (Pojarkova 1951, Tarassov 1952a).

Euphorbia oidorhiza and E. balkhanica were described from specimens collected from the same population, and both names were validly published almost at the same time. According to the imprints on the journal's colophons, the first species name has priority because it was included in a journal's issue dated 13 December 1951, whereas the second species name was published in a journal's issue dated 10 January 1952. This is in agreement with the synonymy first established by Prokhanov (1964).

Euphorbia undulata occurs in steppes and semideserts along the Volga and Don rivers in Russia and Kazakhstan (Kryshtofovich 1931, Prokhanov 1933). This species of short stature is very distinct in the group because of its undulate leaves.

Euphorbia andrachnoides differs from the other species of the series by its ovate leaves with a cordate base, a higher number of pleiochasial branches in a pseudumbel, and sterile stems usually overtopping the inflorescence. It has a rather broad distribution in the Sary-Arqa (Kazakh) Uplands in Kazakhstan, where it grows on various rocky or gravelly substrates at low elevations. This species was considered endemic to Kazakhstan (Gamajunova 1963, Baikov 1999) but was reported by Baikov (2005) from the Aley river in Altay Region of southern Siberia, Russia. The locality in Siberia is rather distantly separated from the main distribution area of the species and should be confirmed because of the deviating morphology of the plants, which were previously referred to E. subcordata (Baikov 1999, 2005).

Euphorbia irgisensis occurs in deserts of western Kazakhstan (Nasimova 1983, Baikov 1999) and possibly in the adjacent Uzbekistan (Erejepov 1978). It is a species of low uplands and characterized by oblong leaves that are broader in the middle part, and a vertical taproot.

Euphorbia saurica is a local endemic of eastern Kazakhstan, found in a single locality in the Saýyr (Saur) Mts. (Baikov 1999). It was until now unique in the series because of its slender rootstock; its leaves are similar to those of E. irgisensis but the number of pleiochasial branches in a pseudumbel is higher. The locality is situated at ca. $1250 \mathrm{~m}$ a.s.1., in a warmer, sunny, less arid climate (Kotukhov 2009).

Euphorbia talassica, described here, is narrowly distributed in the Talas Mountain Range of Kazakhstan and Kyrgyzstan, at $2700 \mathrm{~m}$ (in Kyrgyzstan) or 2150-3200 m a.s.l. (in Kazakhstan). So far, it is known from a single locality in Kyrgyzstan (our data) and four localities in Kazakhstan (Prokhanov 1933, as E. irgisensis aff.; Karmyscheva 1973, as E. prokhanovii; www.plantarium.ru, as E. tianshanica). Its distribution may extend to the Syrdaria Qarataý (Syrdarya Karatau) Mts., from which "E. tianshanica" was also reported (Gamajunova 1963) but that record was not accepted in a later synopsis (Kamelin 1990). Because of its largely oblong leaves, which are broader at the middle part, this species seems to be most similar to $E$. irgisensis (as assumed by Prokhanov 1933), from which it differs by having a slender rootstock, incrassate leaves, and the occurrence at much higher elevations. Remarkably, the other species that has a similar leaf shape, E. saurica, also possesses spreading underground parts but is clearly distinct by a higher number of pleiochasial branches in pseudumbels (8-10 in E. saurica $v s .4-6$ in E. talassica), and also by the presence of pubescence. Among the other species of $E$. ser. Andrachnoides in Central Asia, E. talassica prefers higher elevations (the other species of high elevations, E. buhsei, occurs at 1500-2250 m a.s.l.; Rechinger \& Schiman-Czeika 1964).

The flora of arid lowlands and uplands of northern Central Asia is very different from the flora of its mountainous parts; however, there is a certain overlap between the arid and montane fractions of the flora (Kamelin 1973). Euphorbia saurica and E. talassica, both being narrow endemics in Central Asia (Kamelin 1973), may represent results of local derivations of the arid lowland flora into the mountains. However, their phylogenetic position within E. sect. Esula should be confirmed.

So far, 28 species of Euphorbia are known from Kyrgyzstan with no endemics (Lazkov \& Sultanova 2014), whereas 61 species are reported from Kazakhstan (Abdulina 1999), six species of which are endemics or near-endemics 
of the country. The species diversity and level of endemism of Euphorbia in Kyrgyzstan are the lowest among the central Asian countries (Nasimova 1983) because of the absence of extensive arid lowlands, which harbour many peculiar groups of spurges. The discovery of $E$. talassica, a rare montane element, contributes to the long list of vascular plants endemic to the Talas Range and adjacent mountains and distributed among several plant families (Pavlov 1980).

\section{Acknowledgements}

Sampsa Lommi (Helsinki) is thanked for producing the maps. Ivan Tatanov (St. Petersburg) very kindly provided photocopies of rare literature. Shushana Zhabko (National Library of Russia, St. Petersburg) communicated the date of Tarassov (1952a). This study was supported by the Central Asia Green Road Project (KNA1-1-17, 15-2), jointly developed by Korea and central Asian countries.

\section{References}

Abdulina S.A. 1999: Checklist of vascular plants of Kazakhstan. - Institute of Botany and Phytointroduction, Almaty.

Baikov K.S. [Байков К.C.] 1999: Euphorbiaceae. - In: Peschkova G.A. [Пешкова Г.А.] (ed.), [Flora of Siberia 10]: 38-58. Science Publishers, Novosibirsk. [In Russian].

Baikov K.S. [Байков К.С.] 2005: Euphorbiaceae. - In: Baikov K.S. [Байков К.C.] (ed.), [Synopsis of the flora of Siberia: Vascular plants]: 105-109. Science Publishers, Novosibirsk. [In Russian].

Baikov K.S. [Байков К.С.] 2007: [Spurges of Northern Asia]. — Science Publishers, Novosibirsk. [In Russian].

Baikov K.S. [Байков K.C.] 2009: [A new species of Euphorbia (Euphorbiaceae) from eastern Kazakhstan]. Botanicheskii Zhurnal (Moscow \& Leningrad) 84(4): 108-112. [In Russian].

Berry P.E., Riina R., Peirson J.A., Yang Y., Steinmann V.W., Geltman D.V., Morawetz J.J. \& Cacho N.I. 2016: Euphorbia L. - In: Flora of North America Editorial Committee (eds.), Flora of North America 12: 237-324. Oxford University Press, New York.

Erejepov S.E. [Ережепов C.E.] 1978: [Flora of Qaraqalpaqstan, its economic importance, use and protection]. - Science Publishers, Tashkent. [In Russian].

Gamajunova A.P. [Гамаюнова А.П.] 1963: Euphorbiaceae. - In: Pavlov N.V. [Павлов H.B.] (ed.), [Flora of Kazakhstan 6]: 62-108. Academy of Sciences of the Kazakh SSR, Alma-Ata. [In Russian].

Geltman D.V. 2015: Phytogeographical analysis of Euphorbia subgenus Esula (Euphorbiaceae). — Polish Botanical Journal 60: 147-161.
Govaerts R., Frodin D.G. \& Radcliffe-Smith A. 2000: World checklist and bibliography of Euphorbiaceae (and Pandaceae) 2: 417-921. — The Board of Trustees of the Royal Botanic Gardens, Kew.

Kamelin R.V. [Камелин Р.B.] 1973: [Florogenetic analysis of the native flora of the mountainous Central Asia]. Science Publishers, Leningrad. [In Russian].

Kamelin R.V. [Камелин Р.B.] 1990: [Flora of Syrdaria Qarataý]. - Science Publishers, Leningrad. [In Russian].

Karmyscheva N.X. [Кармышева H.X.] 1973: [Flora and vegetation of the Aqsý-Jabagyly Nature Reserve (Talas Alatau)]. - Science Publishers, Alma-Ata. [In Russian].

Karmyscheva N.X. [Кармышева H.X.] 1982: [Flora and vegetation of western spures of the Talas Alatau $]$ - Science Publishers, Alma-Ata. [In Russian].

Kotukhov Yu.A., Danilova A.N. \& Anufrieva O.A. [Котухов Ю.А., Данилова А.Н. \& Ануфриева О.А.] 2009: [Present status of populations of rare and declining species in eastern Kazakhstan, vol. 2]. — Tethys, Almaty. [In Russian].

Kryshtofovich A.N. [Криштофович А.Н.] 1931: Euphorbiaceae. - In: Fedtschenko B.А. [Федченко Б.А.] (ed.), [Flora of the south-east of the European part of the USSR, vol. 5]. Trudy Glavnogo Botanicheskogo Sada 43: 659-677. [In Russian].

Lazkov G.A. \& Sultanova B.A. [Лазьков Г.А. \& Султанова Б.A.] 2014: [Checklist of vascular plants of Kyrgyzstan]. - United Nations Development Programme, Bishkek. [In Russian].

Lazkov G.A. \& Sennikov A.N. 2017: Taxonomy of two blueflowered juno irises (Iris subgen. Scorpiris, Iridaceae) from the Western Tian-Shan. - Annales Botanici Fennici 54: 297-305.

Ma J. \& Gilbert M.G. 2008: Euphorbia L. - In: Wu Z.-Y. \& Raven P.H. (eds.), Flora of China, vol. 11: 288-313. Science Press, Beijing \& Missouri Botanical Garden, St. Louis.

Nasimova T. [Насимова Т.] 1983: Euphorbiaceae. - In: Adylov T.A. [Адылов Т.A.] (ed.), Conspectus florae Asiae Mediae 7: 47-79. Science Publishers, Tashkent. [In Russian]

Nasseh Y., Nasarova E. \& Kazempour S. 2018: Taxonomic revision and phytogeographic studies in Euphorbia (Euphorbiaceae) in the Khorassan provinces of Iran. - Nordic Journal of Botany 36: e01413, https://doi. org/10.1111/njb.01413.

Nikitin V.V. \& Geldykhanov A.M. [Никитин B.B. \& Гельдыханов А.M.] 1988: [Manual of vascular plants of Turkmenistan]. - Science Publishers, Leningrad. [In Russian].

Pahlevani A.H., Feulner M., Weig A. \& Liede-Schumann S. 2017: Molecular and morphological studies disentangle species complex in Euphorbia sect. Esula (Euphorbiaceae) from Iran, including two new species. - Plant Systematics and Evolution 303: 139-164.

Pavlov V.N. [Павлов В.Н.] 1980: [Plant cover of the Western Tian-Shan]. - Moscow State University, Moscow. [In Russian].

Pazij V.K. [Пазий В.К.] 1959: Euphorbiaceae. — In: Vvedensky А.І. [Введенский А.И.] (ed.), [Flora of Uzbeki- 
stan 4]: 82-123. Academy of Sciences of the Uzbek SSR, Tashkent. [In Russian].

Pojarkova А.І. [Пояркова А.И.] 1950: Euphorbiaceae. — In: Schischkin B.К. [Шишкин Б.К.] (ed.) [Flora of Turkmenia 5]: 44-74. Turkmen Branch of the Academy of Sciences of the USSR, Ashkhabad. [In Russian].

Pojarkova A.I. [Пояркова А.И.] 1951: [A new species of Euphorbia L. from Turkmenia]. - Botanicheskie Materialy Gerbariya Botanicheskogo Instituta Imeni V. L. Komarova Akademii Nauk SSSR. 14: 236-237. [In Russian].

Prokhanov Yа.І. [Проханов Я.И.] 1933: [Systematical review of the spurges of Middle Asia]. - ONTI, Moscow \& Leningrad. [In Russian].

Prokhanov Ya.I. [Проханов Я.И.] 1949: Euphorbia L. In: Schischkin B.K. \& Bobrov E.G. [Шишкин Б.К. \& Бобров Е.Г.] (eds.), [Flora of the USSR 14]: 304-495. Academy of Sciences of the USSR, Moscow \& Leningrad. [In Russian].

Prokhanov Ya.I. [Проханов Я.И.] 1964: [Taxonomic overview of Euphorbia in the USSR. Additions and corrections]. - Novosti Sistematiki Vysshikh Rastenii 1: 226-237. [In Russian].

Rechinger K.H. \& Schiman-Czeika H. 1964: Euphorbiaceae. - In: Rechinger K.H. (ed.), Flora Iranica, vol. 6: 1-48, tables 1-20. Akademische Druck- und Verlaganstalt, Graz.
Riina R., Peirson J.A., Geltman D.V., Molero J., Frajman B., Pahlevani A., Barres L., Morawetz J.J., Salmaki Y., Zarre S., Kryukov A., Bruyns P.V. \& Berry P.E. 2013: A worldwide molecular phylogeny and classification of the leafy spurges, Euphorbia subgenus Esula (Euphorbiaceae). - Taxon 62: 316-342.

Shibkova I.F. \& Kinzikaeva G.K. [Шибкова И.Ф. \& Кинзикаева Г.К.] 1981: Euphorbia L. — In: Ovchinnikov P.N. [Овчинников П.Н.] (ed.), [Flora of the Tajik SSR 6]: 437-471. Science Publishers, Leningrad. [In Russian].

Takhtajan A. 1986: Floristic regions of the world. - University of California Press, Berkeley.

Tarassov R.P. [Тарасов Р.П.] 1952a: [A new species of Euphorbia from Turkmenistan]. - Izvestiya Akademii Nauk Turkmenskoi SSR 1951(2): 83. [In Russian].

Tarassov R.P. [Тарасов Р.П.] 1952b: [Notes on the flora of the Malyi Balkhan]. — Izvestiya Akademii Nauk Turkmenskoi SSR 1952(2): 77-79. [In Russian].

Turland N.J., Wiersema J.H., Barrie F.R., Greuter W., Hawksworth D.L., Herendeen P.S., Knapp S., Kusber W.-H., Li D.-Z., Marhold K., May T.W., McNeill J., Monro A.M., Prado J., Price M.J. \& Smith G.F. (eds.) 2018: International Code of Nomenclature for algae, fungi, and plants (Shenzhen Code) adopted by the Nineteenth International Botanical Congress Shenzhen, China, July 2017. - Regnum Vegetabile 159: I-XXXVIII + 1-254. 